Cite this: Org. Biomol. Chem., 2013, 11, 3484

Received 6th May 2012, Accepted 3rd April 2013

DOI: $10.1039 / c 30 b 25867 j$

www.rsc.org/obc

\section{Tautomerism and metal complexation of 2-acylmethyl- 2-oxazolines: a combined synthetic, spectroscopic, crystallographic and theoretical treatment $\dagger$}

\author{
Roderick C. Jones, ${ }^{a}$ Khrystyna Herasymchuk, $\neq^{\mathrm{b}}$ Tayseer Mahdi, $\ddagger^{\mathrm{b}}$ Anna Petrov, $\neq^{\mathrm{b}}$ \\ Sanja Resanović, $\ddagger^{b}$ Douglas G. Vaughan, $\neq^{c}$ Alan J. Lough, $\S^{d}$ J. Wilson Quail, $\S^{\mathrm{e}}$ \\ Bryan D. Koivisto, ${ }^{b}$ R. Stephen Wylie ${ }^{b}$ and Robert A. Gossage ${ }^{\star b, c, f}$
}

\begin{abstract}
A synthetic, structural and theoretical investigation into the solid-state, solution and gas phase structure(s) of six 2-acylmethyl-4,4-dimethyl-2-oxazolines is reported. Four of these materials, viz. $\alpha$-[(4,5-dihydro-4,4dimethyl-2-oxazolyl)methylene]benzenemethanol (3a), $\alpha$-[(4,5-dihydro-4,4-dimethyl-2-oxazolyl)-methylene]-(4-nitrobenzene)methanol (3b), 1-(4,5-dihydro-4,4-dimethyl-2-oxazolyl)-3,3-dimethyl-1-buten-2-ol (3d) and (E)-1-phenyl-2-((3aR)-3,3a,8,8a-tetrahydro-2H-indeno[1,2-d]oxazol-2-ylidene)ethanone (3f) have been characterised in the solid-state by single crystal $X$-ray diffraction studies. These data represent the first solid-state structural studies of this class of compounds and details the first synthesis and full characterisation of chiral derivative $\mathbf{3 f}$. All four of these materials are shown to exist in the solid phase in the enamine tautomeric form (e.g., 3a is best described as 2-[4,4-dimethyl-2-oxazolidinylidene]-1-phenylethanone) and it is suggested (NMR, IR) that this isomeric form is likely also retained in solution (e.g., $\left.\mathrm{CDCl}_{3}\right)$ as the more stable isomer. An investigation of the relative gas phase stabilities of the three possible (i.e., the (Z)-enol, keto and enamine) isomers of all five compounds by DFT at the B3LYP/6-311G(d) level of theory confirms the latter as the most stable form. The energy differences between the enamine and keto tautomers have been calculated to be the lowest for derivative $\mathbf{3 d}$. These results are compared and contrasted with the previously reported NMR studies of such compounds which have identified the keto form as being a minor (albeit solution) tautomer. Equilibrium solution tautomer distributions for $\mathbf{3 d}$ are found to be solvent dependent. The protonated form of 3a, isolated as the $\mathrm{HSO}_{4}{ }^{-}$salt (i.e. $4 \mathrm{a}$ ), has been further characterised in the solid state by single crystal X-ray diffraction. These data represent the first example of a protonated oxazoline to be structurally elucidated and confirms that upon protonation, the keto (oxazoline) tautomer is the energetically favoured form in the solid-state. This observation is further supported by DFT studies for the gas phase protonated forms of such materials. Further DFT (B3LYP/6-311G(d)) calculations employing the SM8 or SMD solvation models were then applied to address the observed solution isomeric distribution for $\mathbf{3 d}$; these results corroborate the gas phase theoretical treatment and also yield values that predict the higher solution stability of the enamine form as observed, although they fail to account for the existence of the keto form as a minor solution state tautomer. To access the availability of an enol-form, via hypothetical de-protonation to the enolate, compound 3a was treated with hydrated $\mathrm{Cu}\left(\mathrm{NO}_{3}\right)_{2}$ in EtOH solution. The resulting isolated green-coloured product (5), the first metal derivative of this entire class of ligands, is best described (IR, X-ray diffraction)
\end{abstract}

\footnotetext{
${ }^{a}$ School of Chemistry, University of Tasmania, Hobart, TAS 7001, Australia ${ }^{b}$ Department of Chemistry and Biology, 350 Victoria Street, Ryerson University, Toronto, ON M5B 2K3, Canada

${ }^{c}$ Department of Chemistry, Acadia University, Wolfville, NS B4P 2R6, Canada ${ }^{d}$ Department of Chemistry, University of Toronto, 80 St. George Street, Toronto, ON M5S 3H6, Canada

${ }^{e}$ Department of Chemistry, University of Saskatchewan, Saskatoon, SK S7N 5C9, Canada

${ }^{f}$ Centre for Urban Energy, 147 Dalhousie Street, Ryerson University, Toronto, ON M5B 2K3, Canada. E-mail: gossage@ryerson.ca; Fax: +1-416-9795044
}

$\dagger$ Electronic supplementary information (ESI) available: Oxazoles XXIX. DFT calculations, general crystal data, cif files for X-ray data, spectroscopic data for $\mathbf{2 f}$, 3f and 5. CCDC 799949-799951 (3a, 3c-d), 915339 (3f), 860691 (4a), 915340 (5). For ESI and crystallographic data in CIF or other electronic format see DOI: $10.1039 / \mathrm{c} 3 \mathrm{ob} 25867 \mathrm{j}$

$\ddagger$ Undergraduate research participants; these authors contributed equally to this research.

$\S$ Authors to whom correspondence should be directed concerning the crystallographic work; compounds 3a and 3c (E-mail: wilson.quail@usask.ca); 3d, 3f, 4a and 5 (E-mail: alough@chem.utoronto.ca). 
as a coordinated enolate complex, i.e., $\mathrm{Cu}(3 \mathrm{a}-\mathrm{H})_{2}$. Complex $\mathbf{5}$ crystallizes in the $\mathrm{P} 21 / \mathrm{c}$ space group with four molecules in the unit cell. The coordination geometry around the formal $\mathrm{Cu}^{2+}$ metal centre is determined to be highly distorted square planar in nature $\left(\tau_{4}=0.442\right)$. TD-DFT is used to give a reasonable explanation for the intensity of the absorbance band observed in the visible region for solutions of $\mathbf{5}$. These latter experiments strongly suggest that the title class of compounds may have considerable potential as ligands in coordination chemistry and/or metal-mediated catalysis.

\section{Introduction}

Azoles, specifically the 2-oxazoline (i.e., 4,5-dihydro-2-oxazole) sub-class of azoles, represent an important group of chiral auxiliaries and metal binding agents which are used extensively in both enantio-selective catalysis and materials science. ${ }^{1}$ In addition, this heterocycle has been employed for some time as a monomer in polymer chemistry ${ }^{2}$ and as a directing and/or protecting group in organic syntheses; azoles are also present in a wide variety of natural products and synthetic drugs. ${ }^{3,4}$ Our own interests lie in the areas of metal coordination chemistry and ligand design strategies of both chiral and achiral oxazolines. ${ }^{5}$ In this regard, we became interested in a class of oxazoline-derived organics first described by the late A. I. Meyers; ${ }^{6}$ simple protocols (Scheme 1 ) for a variety of other examples being revealed sometime later by Tohda and coworkers. $^{7 a-c}$ These compounds, in one tautomeric form, contain an oxazoline linked to a ketone functionality via a carbon atom emanating from oxazoline ring position-2 (Scheme 1). ${ }^{6,7}$ A potential application of these materials involves the sequestering of the enol-form (Scheme 1: A) via $\kappa^{2}-N, O$ metal chelation either proceeding or subsequent to $\mathrm{H}^{+}$ loss (i.e., bidentate metal-binding via the resulting enolate). ${ }^{8}$ There are several reasonable resonance forms for this class of heterocycles including two oxazoline forms (Scheme 1: A [enol] and $\mathbf{B}$ [keto]) and a secondary amine of the enamine class (Scheme 1: C).

The investigation reported herein examines several of these materials in both the solid-state (X-ray diffraction, IR), solution

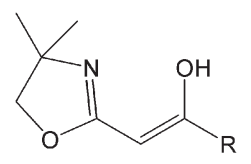

A

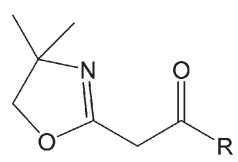

B

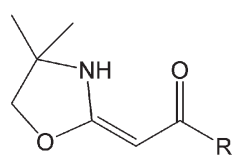

C 3a: $\mathrm{R}=\mathrm{Ph} ; \mathbf{3 b}: \mathrm{R}=\mathrm{Ph}-4-\mathrm{OMe}$;

3c: $\mathrm{R}=\mathrm{Ph}-4-\mathrm{NO}_{2} ; 3 \mathrm{~d}: \mathrm{R}=t-\mathrm{Bu} ; 3 \mathrm{e}: \mathrm{R}=\mathrm{Me}$

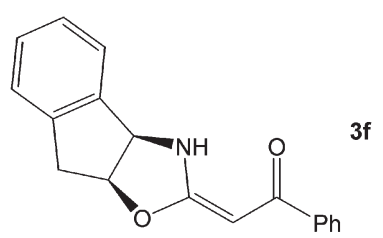

Scheme 1 Synthetic scheme leading to 3-type derivatives (enamine isomeric product shown); conditions: (i) $2 \times \mathrm{RC}(=\mathrm{O}) \mathrm{Cl} / \mathrm{NEt}_{3} / \mathrm{MeCN} / \Delta$; (ii) $\mathrm{KOH} /$ alcohol; (iii) $+1 / 2 \times \mathrm{Cu}\left(\mathrm{NO}_{3}\right)_{2} \cdot 2.5 \mathrm{H}_{2} \mathrm{O} / \mathrm{EtOH} ;-\mathrm{HNO}_{3}-1.25 \mathrm{H}_{2}$.
(NMR) and in a theoretical sense (DFT) to determine the relative stabilities and properties of such tautomeric possibilities. ${ }^{9}$ In this regard, reaction of enamine $\mathbf{3 a}$ with divalent copper nitrate results in the isolation and full characterisation of the corresponding bis- $\kappa^{2}-\mathrm{N}, \mathrm{O}$-enolate complex. This confirms the accessibility, at least under these conditions, of a hypothetical enol-tautomer of this class of materials and thus establishes the groundwork for a coordination chemistry exploration of ligands such as 3a. A further consequence of this work is the establishment of the facile accessibility of chiral versions of this potential ligand class via example 3f. The forms depicted in Scheme 1 also serve to demonstrate that this class of heterocycles will allow for a rare opportunity ${ }^{10}$ to examine an enamine, keto and enol-trio, not only in terms of their stabilities, but also with respect to their general structural properties in terms of the resonance-assisted H-bonding (RAHB) theory. ${ }^{11}$

\section{Results and discussion}

As mentioned previously, compounds such as $\mathbf{3 a - 3 e}$ have found application as useful intermediates in the syntheses of other heterocyclic materials. ${ }^{6,7}$ Both Meyers ${ }^{6}$ and Tohda $^{7 a-c}$ independently surmised that the three tautomers, shown in Scheme 2, could be accessible for these compounds and that this aspect might be a contributing factor to their observed reactivity. Indeed for alkyl derivatives such as $\mathbf{3 e}$, both researchers reported a minor solution tautomer ( 10\%) unequivocally identified as the keto-form ${ }^{12}$ in addition to a major species assigned to the enamine. This latter conclusion was supported by ${ }^{13} \mathrm{C}$ NMR data. ${ }^{6,7}$ No theoretical studies or any solid-state characterisation (X-ray) data have been reported for any of these materials. An initial selection of three of these compounds was chosen for investigation by single crystal X-ray diffraction and these results are described below.

\section{Solid-state characterisation}

Suitable single crystals of compounds $\mathbf{3 a}, \mathbf{3 c}$ and $\mathbf{3 d}$ (Scheme 2) were obtained by re-crystallisation of the said materials from hexanes-toluene mixtures. Fig. 1-3 give graphical representations $\left(\right.$ ORTEP $\left.^{13}\right)$ of a unit cell molecule of each of the respective compounds.

Details of the crystal data and tables of bond lengths and angles can be found in the ESI. $\dagger$ The general crystal parameters reveal nothing unusual nor surprising. ${ }^{14}$ However, the identification of an $\mathrm{N}-\mathrm{H}$ group and a formal $\mathrm{C}=\mathrm{C}$ initiating from ring position-2 on the heterocycle are observations of 


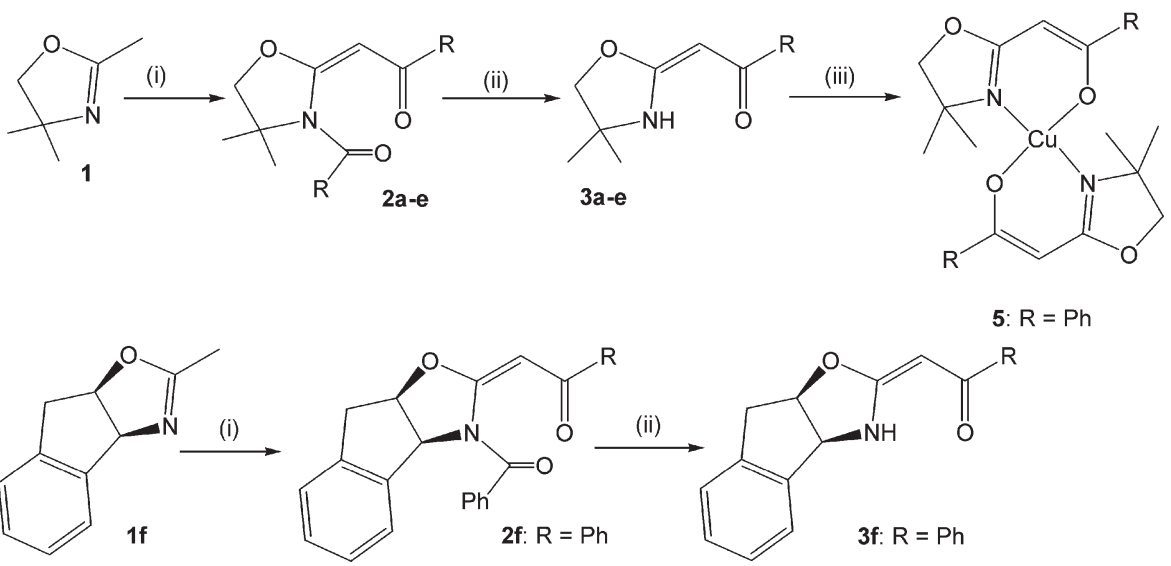

Scheme 2 Schematic representations of the isomers and organic compounds studied herein.

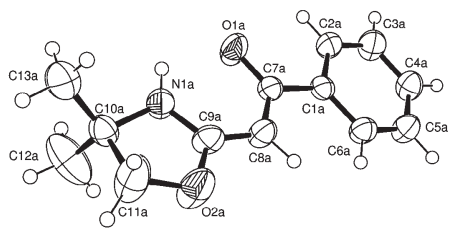

Fig. 1 ORTEP representation of a unit cell molecule of $\mathbf{3} \mathbf{a}$, thermal ellipsoids are at the $50 \%$ probability level.

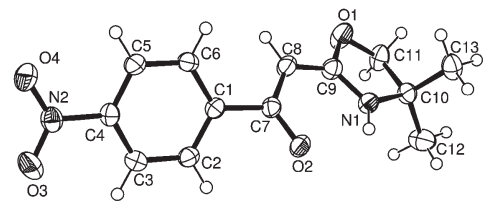

Fig. 2 ORTEP representation of a unit cell molecule of 3c, thermal ellipsoids are at the $50 \%$ probability level.

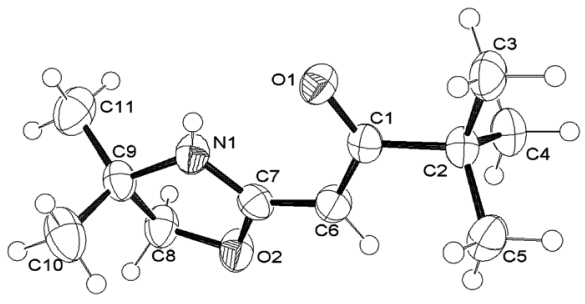

Fig. 3 ORTEP representation of a unit cell molecule of $\mathbf{3} \mathbf{d}$, thermal ellipsoids are at the $50 \%$ probability level.

obvious relevance. These results unequivocally identify all three of these compounds as existing in the enamine isomeric form (Scheme 1: C) in the crystalline solid-state. ${ }^{15}$ This tautomeric situation has been previously noted in, for example, compounds such as $(E)$ - $N$-(1,3-oxazolidin-2-ylidene)benzami$\mathrm{de}^{16 a}$ and other related species. ${ }^{10 a, 16 b}$ It is therefore suggested that this isomeric form is the likely thermodynamically more stable solid-state isomer for such compounds.

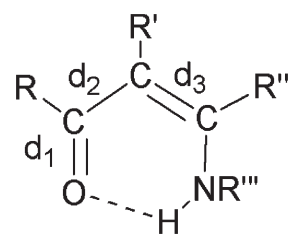

Scheme 3 Bond labelling of a hypothetical $\beta$-enaminone for discussions of RAHB.

Resonance assisted H-bonding (RAHB) is a theory first introduced by Gilli et al. ${ }^{11}$ and is used to describe a special form of intramolecular H-bonding and its effect(s) on ground state molecular structure. ${ }^{11,17,18}$ This concept is used to evaluate the level of $\mathrm{H}$-bonding and bond length distortions between groups $\mathrm{D}-\mathrm{H} \cdots \mathrm{A}=$ where $\mathrm{D}$ and $\mathrm{A}$ are atoms which are connected through a $\pi$-conjugated system. A schematic representation of such a generalised system, with some selected bond labelling, appears in Scheme $3 .{ }^{18}$ Compounds such as 3a therefore provide an opportunity to examine the presence of the effects attributed to RAHB in enamine-containing molecules. If there is appreciable $\pi$-delocalisation present in a particular system, such as that depicted in Scheme 3, this will affect the various interatomic distances $d_{1}$ through $d_{4}$ in the following manner: (i) bond lengths $d_{2}$ and $d_{3}$ tend to become equal and (ii) $d_{4}$ bond lengths shorten and $d_{1}$ bond lengths increase $v s$. that of typical ${ }^{14}$ values. The common values for the relevant interatomic distances are shown in Table 1 (taken from the benchmark study of Allen et al.: ref. 14) as are the observed $d_{1}-d_{4}$ distances found in the solid-state for $3 \mathbf{a}, 3 \mathbf{c}$ and 3d. An examination of Table 1 reveals that in the case of the enamines examined here, the $d_{1}$ (i.e., carbonyl $\mathrm{C}=\mathrm{O}$ ) bond lengths do indeed elongate $(\sim 2-3 \%)$ in all three cases and the $d_{4}$ (i.e., C-NHR"') parameter is shorter than typical values by about $1-3 \%$. Significant shortening of $d_{2}(\sim 3 \%)$ and lengthening of $d_{3}(\sim 3 \%)$ is also observed, but these latter two values are still significantly different from one another by an average of more than $0.03 \AA$. Although more examples will be necessary to make a more concrete conclusion, it can be suggested based 
Table 1 Bond lengths $d_{1}-d_{4}$ of $\beta$-enaminones with respect to discussions of RAHB.

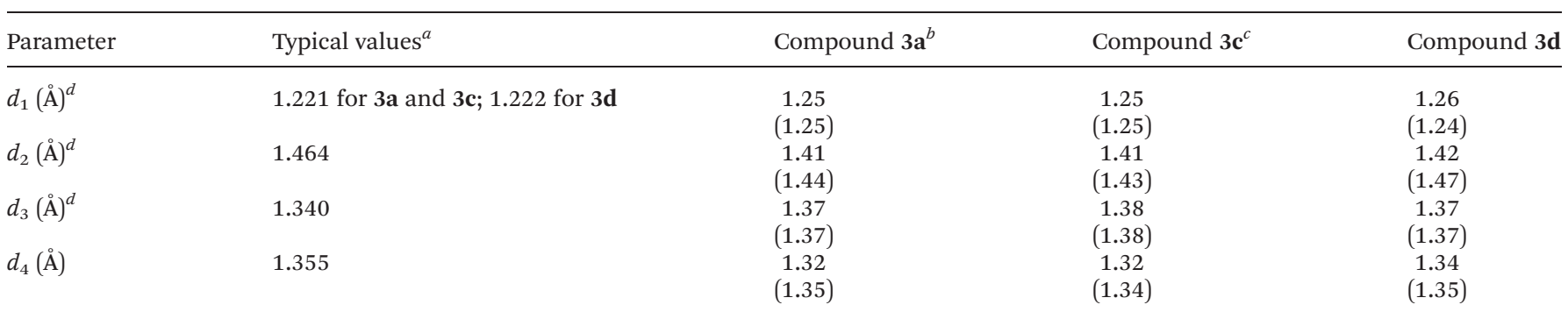

${ }^{a}$ Ref. $14 .{ }^{b}$ Three molecules in the unit cell: average values shown. ${ }^{c}$ Four molecules in the unit cell: average values shown. ${ }^{d}$ Calculated (DFT) values in parentheses.

on these simple observations that the H-bond resulting from the $\mathrm{N}-\mathrm{H} \cdots \mathrm{O}=\mathrm{C}$ interaction appears to be relatively weak in these systems. ${ }^{17,18}$

\section{Solution NMR studies}

In an attempt to observe and/or clarify the isomeric distributions in solution of the phenyl compounds such as $\mathbf{3 a - c}$, an examination by VT- ${ }^{1} \mathrm{H}$ NMR spectroscopy was initiated. Unfortunately, under both low $\left(-78^{\circ} \mathrm{C}\right)$ and high $\left(+40^{\circ} \mathrm{C}\right)$ temperature conditions only a single (non-keto) isomer was observed in the case of $3 \mathbf{a}\left(\mathrm{CDCl}_{3}\right.$ solution) and indeed a similar result is noted for the RT spectrum of $3 \mathbf{a}$ recorded in acetone- $\mathrm{d}_{6}$. These observations are consistent with the room temperature (RT) data reported by Tohda. ${ }^{7 a, c}$ As mentioned previously, alkyl derivative $3 \mathbf{e}$ reveals the presence of a minor (unequivocally keto) species in addition to the major, enamine (NMR: ${ }^{6,7 c}$ vide supra) form. Our independent observations here confirm both Meyers $^{6}$ and Tohda $^{7 c}$ reports of the minor $(\sim 10 \%)$ keto $3 \mathbf{e}$ tautomer being present at RT in chloroform-d. tert-Butyl compound $3 \mathbf{d}$ has also been examined previously via ${ }^{1} \mathrm{H}$ NMR spectroscopy. This material has been reported to exhibit a single set of resonances, again presumed to be representative of the enamine, when examined in $\mathrm{CCl}_{4}$ solution by NMR spectroscopy. ${ }^{7 a}$ In contrast, our observations confirm the presence of the minor keto form in $\mathrm{CCl}_{4}$ (external $\mathrm{CDCl}_{3}$ lock) being present in about $6.1 \%$. Our further examination of this compound dissolved in $\mathrm{CDCl}_{3}$ also reveals the presence of this same minor species $\left(8.1 \%: \delta_{\mathrm{H}}=3.97\left[\mathrm{~s}, 2 \mathrm{H}, \mathrm{O}-\mathrm{CH}_{2}\right], 3.63[\mathrm{~s}\right.$, $\left.2 \mathrm{H},-\mathrm{CH}_{2}-\right], 1.29\left[\mathrm{~s}, 6 \mathrm{H},-\mathrm{CH}_{3}\right], 1.18\left[\left(\mathrm{~s}, 9 \mathrm{H},-\mathrm{C}\left(\mathrm{CH}_{3}\right)_{3}\right]\right)$ in addition to the major enamine tautomer. These data suggest that solvent influences may be an important aspect of the isomer distributions in these materials ${ }^{17,19}$ and that such interactions could be energetically greater than any influences due to RAHB. ${ }^{6,7,17,19,20}$ Calculations (DFT calculations see $\mathrm{ESI} \dagger$ ) have revealed that upon protonation, the keto tautomers are considerably lower in energy than the respective protonated enamine or enol species $\left(\sim 40 \mathrm{~kJ} \mathrm{~mol}^{-1}\right)$. Therefore, the attempted syntheses of the protonated form of $\mathbf{3 a}$ and $\mathbf{3 d}$ was carried out (reaction of $\mathbf{3 a} / \mathbf{d}$ and $\mathrm{H}_{2} \mathrm{SO}_{4}$ ) and the resulting products (e.g., $\mathbf{4 a} / \mathbf{d})$ isolated as a crystalline solids. $†$ The nature of these materials was then confirmed by single crystal X-ray diffraction (Fig. 4) and these data represent, to our knowledge,

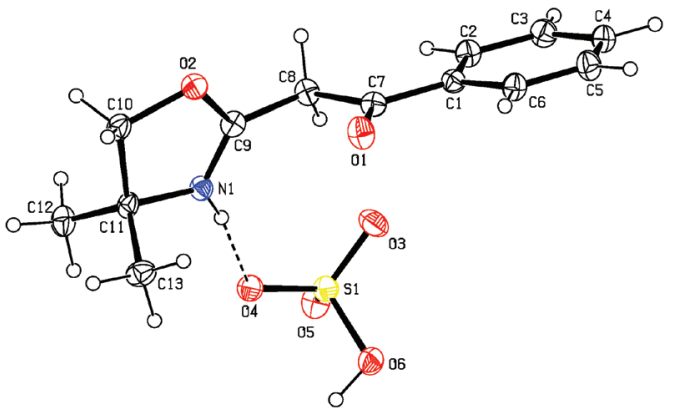

Fig. 4 ORTEP representation of a unit cell molecule of $\mathbf{4 a}$, thermal ellipsoids are at the $50 \%$ probability level.

the only crystallographically characterised protonated oxazoline in the literature.

As expected, the data are wholly consistent with a keto-form for crystalline $4 \mathrm{a}$; distinct $\mathrm{N}=\mathrm{C}(d=1.29 \AA)$ and clearly apparent $\mathrm{sp}^{3}$-hybridised $\mathrm{C}$ atom emanating from azole ring position$2\left(\angle \mathrm{C}-\mathrm{CH}_{2}-\mathrm{C}=111.3^{\circ}\right)$ are observed. $\nmid$ These data corroborate the DFT calculations on the relative stability of the keto following ring N-protonation. Unfortunately, samples of 3d treated in this way (to yield the desired $\mathbf{4 d}$ ) resulted in the isolation of crystalline material of the oxazoline ring-opened ester product formed by the attack by water. $\uparrow$ Therefore, only solution observations of $4 \mathbf{d}$ could be reliably reported. The ${ }^{1} \mathrm{H}$ NMR chemical shift data for $4 d \mathrm{CDCl}_{3}: \delta_{\mathrm{H}}=7.51[\mathrm{br}], 6.30[\mathrm{br}], 4.17[\mathrm{~s}, 2 \mathrm{H}$, $\left.\mathrm{O}-\mathrm{CH}_{2}\right], 3.81\left[\mathrm{~s}, 2 \mathrm{H},-\mathrm{CH}_{2}-\right], 1.41\left[\mathrm{~s}, 6 \mathrm{H},-\mathrm{CH}_{3}\right], 1.15[(\mathrm{~s}, 9 \mathrm{H}$, $\left.\left.-\mathrm{C}\left(\mathrm{CH}_{3}\right)_{3}\right]\right)$ do not correspond to the observed keto-form in samples of $3 \mathbf{d}$ in $\mathrm{CDCl}_{3}$ mentioned above, thus ruling out a possible assignment of the latter as $\mathbf{4 d}$ due to protonation of 3d by residual $\mathrm{HCl}$ present in chloroform. ${ }^{19 f, g, 20}$

To investigate this notion further, a sample of compound 3d was further examined $\left({ }^{1} \mathrm{H}\right.$ NMR) after dissolution in $\mathrm{C}_{6} \mathrm{D}_{6}$, acetone- $\mathrm{d}_{6}, \mathrm{MeOH}-\mathrm{d}_{4}$ and DMSO- $\mathrm{d}_{6}$. The ratio of enamine to

T Crystallographic characterisation of the products resulting from the ringopening of protonated $\mathbf{3 d}$ will be reported separately. For related examples, see: (a) A. M. Korolev, L. T. Eremenko and L. V. Meshikhina, Izv. Akad. Nauk. Ser. Khim., 1999, 812-814 (Russ. Chem. Bull., 1999, 48, 808-809); (b) R. A. Gossage, H. A. Jenkins and J. W. Quail, J. Chem. Crystallogr., 2010, 40, 272-277; (c) P. Deslongchamps, S. Dubé, C. Lebreux, D. R. Patterson and R. J. Taillefer, Can. J. Chem., 1975, 53, 2791-2807; (d) P. Deslongchamps, C. Lebreux and R. Taillefer, Can. J. Chem., 1973, 51, 1665-1669. 
keto forms $\left(K_{\mathrm{T}}\right)$ in these solvents (RT) were determined to be $24.3 ; 27.5 ; 6.4$ and 40.9-to-one, respectively. Examination of these values does not lead to a logical correlation between $K_{\mathrm{T}}$ and common solvent parameters such as donor number (DN), acceptor number (AN) or relative permittivity. ${ }^{19 f, g, 21}$ Such an investigation will be part of a separate treatment of these effects.

\section{Theoretical gas phase and solution (DFT) treatments}

The solid-state structures of compounds $\mathbf{3 a}, \mathbf{3} \mathbf{c}$ and $\mathbf{3 d}$ determined above (X-ray) can be compared with calculated structures for the gas phase. $\uparrow$ Using the solid-state structure of $\mathbf{3 a}$, a study was made of the effect of the selected basis set on the results of the geometric optimisation. Calculations were carried out with the B3LYP/6-31G(d), 6-311G(d) and 6-311G(d,p) basis sets and the bond lengths, angles and torsion angles compared thereafter. Calculations with the 6-311G(d) basis set provided very good agreement with the experimental values, similar to but better than the results obtained from using the 6-31G(d) basis set. Subtle differences in the calculated structure of $\mathbf{3 a}$ when compared to the solidstate structure were consistent with the expected effects of crystal packing. The geometrically-optimised structure with the higher level 6-311G(d,p) basis set was not noticeably improved and not surprisingly required significantly more computation time to complete. Therefore, the 6-311G(d) basis set was considered the best compromise between accuracy and computational time requirements and was used accordingly for structure calculations of all the molecular isomers in this study. A comparison of the bond lengths, bond and torsion angles for the solid-state $v s$. DFT determined gas phase structures for $3 \mathbf{a}, \mathbf{3} \mathbf{c}$ and $\mathbf{3 d}$ can be found in the ESI $\dagger$ and in Table 1. As noted in Table 2, in all five cases (3a-e), the enamine tautomer is calculated to be the most stable gas phase isomeric form, followed by the enol form. The keto-

Table 2 Calculated gas phase energies (DFT: B3LYP/cc-pVTZ) for the tautomers of 3a-e

\begin{tabular}{lc}
\hline Tautomer & $\begin{array}{c}\text { Relative energy differences to } \\
\text { enamine form }\left(\mathrm{kJ} \mathrm{mol}^{-1}\right) \text { in gas phase }\end{array}$ \\
\hline 3a-enamine & 0 \\
3a-enol & +6.81 \\
3a-keto & +29.88 \\
3b-enamine & 0 \\
3b-enol & +9.02 \\
3b-keto & +26.36 \\
& 0 \\
3c-enamine & +11.30 \\
3c-enol & +40.55 \\
3c-keto & 0 \\
3d-enamine & +4.06 \\
3d-enol & +30.89 \\
3d-keto & 0 \\
3e-enamine & +4.47 \\
3e-enol & +30.23 \\
3e-keto &
\end{tabular}

isomer is estimated to be the least stable ground state configuration. This result is in contrast to the solution $\left(\mathrm{CDCl}_{3}\right)$ phase observations, notably for $\mathbf{3 d}$ and $\mathbf{3 e}$ in which both the keto (minor) and the enamine (major) isomer are present. ${ }^{6,7}$

In relation to the idea of RAHB, an examination of the calculated structure of the enol tautomer of 3a was carried out to evaluate the potential energetic contributions of RAHB in this particular isomeric form. Average ${ }^{14}$ bond length values for such enols are 1.333, 1.362, 1.455 and $1.314 \AA$ respectively, for the $d_{1}$ to $d_{4}$ parameters (Scheme 3 ). The calculated values of enol-3a are in quite close agreement to these values for related known systems $(1.34,1.37,1.44$ and $1.29 \AA$ respectively: ESI $\dagger$ ). ${ }^{14}$ This result gives credence to the hypothesis that RAHB is also weak for this tautomer in a similar way as was found for the more stable enamine form (vide supra).

It appears from the observed data obtained by us and others that solvation may be an important contributor to the observed tautomeric distribution(s). Therefore, a theoretical study (DFT: B3LYP/6-311G(d)) was carried out on 3d which included the solvation modelling parameters SM8 or SMD. $\dagger^{22}$ These treatments of solution phenomena have been found to be useful ${ }^{22,23}$ in some cases for predicting solvation enthalpies and the relative stability of tautomeric isomers. ${ }^{23}$ Data for this investigation is tabulated in the ESI as Table S-3. $\dagger$ This data clearly parallel the gas phase studies, confirming the stability of the enamine tautomer in each case, but failing to account for the observation of the keto-tautomer. The results are, however, consistent with an energetically accessible enol-tautomer. In terms of applying such findings to metal-ligand complex syntheses, one might suggest that materials such as 3a may be amenable to conversion to a metal-bound enolate formed via proton loss. This concept is addressed below.

\section{Chiral derivatives - proof-of-principle: the synthesis of $3 f$}

The use of organic fragments as ligands in both coordination chemistry and catalysis has been a subject of growing importance in recent years as the interdisciplinary nature of synthesis continues to expand. A modular ligand design strategy, in which a similar set of protocols and/or starting materials can be used, facilitates the production of large libraries of ligands that can have pre-established steric and/or electronic properties. Our desire to use the Tohda inspired compounds as potential ligands is further enhanced by the realisation that many chiral 2-methyl-2-oxazoline precursors are available or readily synthesised. It has been noted that unsubstituted 2-methyl-2-oxazoline itself can be a troublesome reagent to employ under such methodology ${ }^{7 g}$ and hence this substrate provides a potential caveat to the realisation of such a ligand library. We therefore felt that the synthesis of a chiral analogue of $\mathbf{3 a - 3 \mathbf { d }}$ would suggest that this potential class of ligands was worthy of further synthetic scrutiny. In this regard, the use of $(3 \mathrm{a} S, 8 \mathrm{a} R)$-2-methyl-8,8a-dihydro-3a $H$-indeno[1,2- $d]$ oxazole (1f: Scheme 2), readily available from $(1 S, 2 R)$-cis-1-amino2 -indanol, was chosen as a proof-of-principle reactant. Treatment of $\mathbf{1 f}$ under identical conditions as those employed in the synthesis of $\mathbf{2 a}$ (and subsequently 3a) were found, to our 


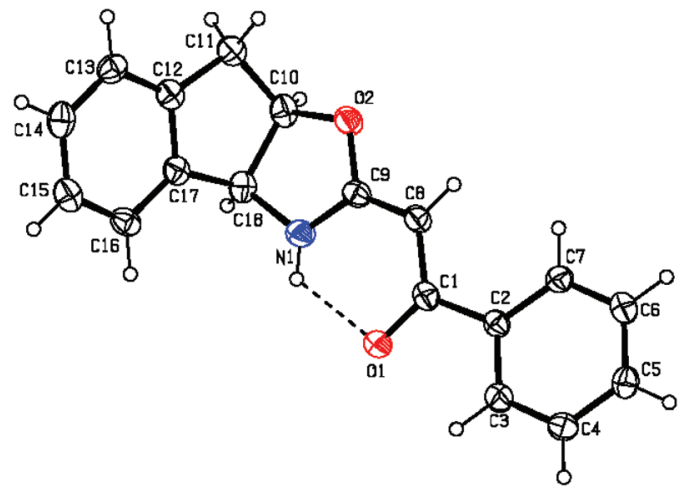

Fig. 5 ORTEP representation of a unit cell molecule of $\mathbf{3} \mathbf{f}$, thermal ellipsoids are at the $50 \%$ probability level.

delight, to yield chiral derivative $3 \mathbf{f}$ in reasonable overall yield (see Experimental) without employing column chromatography. As observed previously for aryl-derivatives such as $\mathbf{3 a}$, no spectroscopic evidence for a second tautomer was observed via NMR spectroscopy. Isolation of $\mathbf{3 f}$ as single crystals and examination by X-ray crystallography unequivocally confirmed the nature of the structure of the desired material and again identifies the enamine form as the stable solid-state tautomer (Fig. 5). This promising result opens a gateway for an extensive examination of potential chiral ligands for applications in enantio-selective substrate modification.

\section{Sequestering an enolate - metal complex formation via $3 a$}

The solid-state and solution examination of the materials described herein has clearly indicated the preference of the enamine form with only alkyl derivatives displaying the spectroscopic presence of the keto tautomer. Despite our calculations to the contrary, unequivocal observation or isolation of the hypothetical enol form has not been observed. The sequestering of an enol form, as a precursor to metal-bound formally anionic enolates, would make these materials even more attractive from both a coordination chemistry (e.g., 3a) and enantio-selective catalysis (3f) point of view. Thus, in our opinion a further fundamentally attractive aspect of these compounds is their potential as ligands. We therefore tested 3a in reactions with hydrated $\mathrm{Cu}\left(\mathrm{NO}_{3}\right)_{2}$ in an attempt to replace the nitrate and aqua ligands with two equivalents of a hypothetical enolate derived via proton loss from 3a. This chemistry is prompted by the known propensity of $\mathrm{Cu}^{2+}$ ions to form stable and isolable metal-enolate ${ }^{24}$ and hence this reaction provides a good starting point for a coordination chemistry study. The connection between the structure of a deprotonated enolate such as $[\mathbf{3 a}-\mathrm{H}]^{-}$and the highly successful $\beta$-ketoamine class of ligands, is also of obvious relevance. ${ }^{25}$ The treatment of light yellow-coloured solutions of $\mathbf{3 a}$ with a one-half equivalent of $\mathrm{Cu}\left(\mathrm{NO}_{3}\right)_{2} \cdot 2.5\left(\mathrm{H}_{2} \mathrm{O}\right)$ leads to an immediate colour change to deep green. Isolation of the resulting green powder (5: Experimental), followed by characterisation and crystallisation of this material, reveals elemental analyses data consistent with the formation of a complex of stoichiometry $\mathrm{Cu}(3 \mathrm{a}-\mathrm{H})_{2}$. To

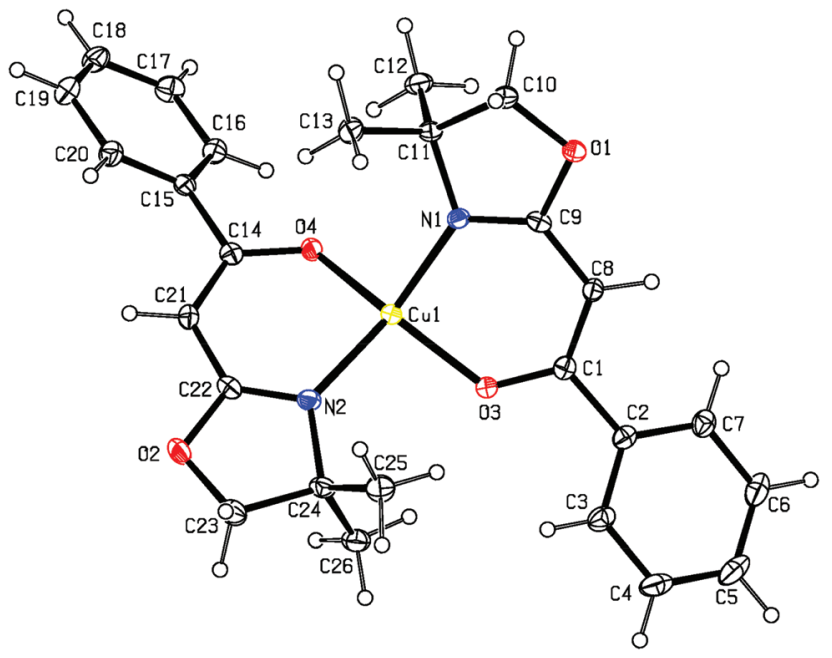

Fig. 6 ORTEP representation of a unit cell molecule of $\mathbf{5}$, thermal ellipsoids are at the $50 \%$ probability level.

unequivocally confirm the structural nature of $\mathbf{5}$, a single crystal X-ray diffraction study was again undertaken. Complex 5 crystallises in the $P 21 / c$ space group (Table S-1†); a schematic representation of a unit cell molecule of 5 is shown in Fig. 6 . These data confirm the coordination of two units of the predicted enolate anion resulting from the de-protonation of $3 \mathbf{a}$. The resulting product 5 is a mononuclear formally $\mathrm{Cu}^{2+}$ species with trans-spanning $\mathrm{N}$ - and O-donor atoms (i.e., $\mathrm{K}^{2}$ $\mathrm{N}, \mathrm{O}$-chelating) from the two ligands obviously arriving via formal loss of water and $\mathrm{HNO}_{3}$. The IR and solution UV/Vis. data are likewise consistent with this formulation. The coordination sphere around the metal centre is best described as highly distorted square planar in nature with a calculated Houser $\tau_{4}$ value of $0.441 .{ }^{26}$ Bond lengths and angles $\dagger$ of this complex are similar to related $\mathrm{Cu}$-oxazoline and related compounds with a trans $-\mathrm{N}_{2} \mathrm{O}_{2}$ ligand atom donor set and are likewise unsurprising $^{27,28}$ although strictly square planar is a more common geometry within similar species. ${ }^{27 a-d, o-q}$ The main visible absorption band $\left(\lambda_{\max }=443 \mathrm{~nm}\right)$ cannot be adequately explained by a simple d-d transition model due to the relatively large $\varepsilon$ value $\left(>10^{3}\right)$. We therefore examined this complex by time dependent DFT (TD-DFT) employing the B3LYP-LANDZD basis set. These results (ESI $\dagger$ ) clearly indicate the interaction of two, primarily ligand-based, MOs and a predominately metal-based LUMO and hence this observation can be best described as ligand-metal charge transfer in nature.

\section{Conclusions}

An examination of the solid-state, solution and gas phase tautomers for a number of 2-acylmethyl-2-oxazolines has been carried out and the first solid-state structural studies of this class of compounds has been revealed. The stability of the possible isomers of these materials seems to be phase 
dependent with solely the enamine isomer being found in the (crystalline) solid-state and dominating the solution phase. Keto isomers are observed in solution for the alkyl derivatives $\mathbf{3 d}$ and 3e; this appears to be a solvent dependent observation. The enol form has not been unequivocally observed but is calculated (DFT) to be a more stable gas phase isomer than the keto-forms. An examination of the potential of RAHB as an energetic contribution to the stability of the enamine and enol forms of a number of these materials was also examined and it is surmised that such contributions are likely to be fairly weak in these systems. The B3LYP/6-311G(d) basis set was found to be a suitable level of theory to emulate the solid-state molecular properties of compounds such as 3a and no clear advantage to employing the B3LYP/6-311G(d,p) basis set was found. A further result of these investigations has been the first isolation and solid-state characterisation of any protonated oxazoline (4a) and, under these conditions, the keto isomer is clearly established by crystallography and theoretical calculations to be the more stable form. This series of organic derivatives has been expanded to include a chiral analogue (i.e., 3f) based on the utilisation of the known 2-methyl-2-oxazoline derivative $(3 \mathrm{a} S, 8 \mathrm{a} R)$-2-methyl-8,8a-dihydro-3a $H$-indeno $[1,2-d]$ oxazole. The new compound $\mathbf{3} \mathbf{f}$ is formed under similar reaction protocols to those disclosed by Tohda and co-workers. One of the title materials (3a) has also been tested for the first time in the synthesis of a transition metal coordination complex. The resulting compound formed between $\mathrm{Cu}^{2+}$ ions in the presence of excess $\mathbf{3 a}$ is shown to be derived from deprotonation of the organic fragment and coordination, in a $\kappa^{2}-\mathrm{N}, \mathrm{O}$-chelating sense, of a resulting enolate. An expanded exploration into the use of this class of potential anionic ligands is currently underway.

\section{Experimental}

\section{General remarks}

All chemical reagents were purchased commercially and used as received. Melting points were determined on a Fisher Scientific Model 12-144 melting point apparatus and are uncorrected. IR spectra were recorded as $\mathrm{KBr}$ pellets using a Perkin Elmer Spectrum One IR spectrometer and near-IR spectra were recorded from $\mathrm{CCl}_{4}$ solutions on a Varian Carey $5 \mathrm{UV} /$ Vis/nearIR spectrophotometer. ${ }^{1} \mathrm{H}$ and ${ }^{13} \mathrm{C}\left\{{ }^{1} \mathrm{H}\right\}$ NMR spectra were recorded in $\mathrm{CDCl}_{3}$ solution or other solvents as indicated at RT by a Bruker Avance 70 AC-400 NMR spectrometer. Spectra are referenced to external TMS $(\delta=0.00 \mathrm{ppm})$ which is in turn assigned by the residual non-deuterated solvent as internal standard. The syntheses of $\mathbf{3 a}, \mathbf{3} \mathbf{c}$ and $\mathbf{3 d}$ were carried out as described previously using 2,4,4-trimethyl-2-oxazoline (1) which is first converted to the corresponding di-acylated products (2: Scheme 1). ${ }^{7 a-c}$ Toluene was used in lieu of benzene ${ }^{7 a}$ for the purposes of re-crystallization for $\mathbf{3 a}, \mathbf{3 c}$ and $\mathbf{3 d}$. Compound $3 \mathbf{e}$ was synthesised as reported by Meyers et al. ${ }^{6}$ The purity of all of the products was confirmed by a combination of $\mathrm{mp}$ and IR and NMR spectroscopies. The synthesis of $\mathbf{4 a}$ and attempted synthesis of $\mathbf{4} \mathbf{b}$ was carried out by the addition of excess conc. $\mathrm{H}_{2} \mathrm{SO}_{4}$ to a methanol solution of the organic starting material; crystals were obtained by slow evaporation of the resulting mixture. These materials were only examined by NMR spectroscopy and/or X-ray diffraction and hence were not characterised further nor purified. The examination of compounds 3a, 3c, 3d, 3f, 4a and 5 via single crystal X-ray diffraction was carried out as described ${ }^{5 a, d, e}$ previously. $\dagger$

Synthesis of $3 \mathbf{b} .^{7,29}$ Using similar reaction protocols to those described by Tohda et al. (Scheme 1), ${ }^{7 a}$ a sample of 2,4,4-trimethyl-2-oxazoline (1: $5.65 \mathrm{~g}$ : $50.0 \mathrm{mmol}$ ) was placed in a $500 \mathrm{~mL}$ round-bottomed flask and heated to reflux temperature for $3 \mathrm{~h}$ in the presence of 4-methoxybenzoyl chloride (17.05 g: $100 \mathrm{mmol}), \mathrm{NEt}_{3}(17.4 \mathrm{~mL}: 125 \mathrm{mmol})$ and acetonitrile $(100 \mathrm{~mL})$. The mixture was then cooled, filtered and all volatile components of the reaction mixture were then removed in vacuo; the residue was then treated with $\mathrm{CHCl}_{3}$ $(50 \mathrm{~mL})$ and water $(50 \mathrm{~mL})$. The organic layer was washed with $5 \%$ aq. $\mathrm{NaHCO}_{3}(15 \mathrm{~mL} \times 3)$, dried $\left(\mathrm{Na}_{2} \mathrm{SO}_{4}\right)$, filtered and the solvents removed by rotary evaporation. The crude solid material was then recrystallised (hot hexanes) and then re-dissolved in EtOAc $(100 \mathrm{~mL})$, extracted with dil. $\mathrm{KOH}$, dried $\left(\mathrm{Na}_{2} \mathrm{SO}_{4}\right)$, and then evaporated. This procedure yielded the diacyl product $2 \mathrm{~b}$ (9.77 g: $51 \%$ ) in the form of a pale yellow powder (mp: $\left.175-176^{\circ} \mathrm{C}\right) .{ }^{30}$ To a sample of $\mathbf{2 b}$ isolated in this way (3.50 g: $9.18 \mathrm{mmol}$ ), a solution of $100 \mathrm{~mL}$ of $1.5 \mathrm{M}$ methanolic $\mathrm{KOH}$ was added. The mixture was stirred at RT for $16 \mathrm{~h}$, filtered, and then the volatile components were removed in vacuo. The residue was suspended in water $(50 \mathrm{~mL})$ and then extracted with $\mathrm{CHCl}_{3}(20 \mathrm{~mL})$. The organic layer was then washed with water (thrice: $15 \mathrm{~mL})$, dried $\left(\mathrm{Na}_{2} \mathrm{SO}_{4}\right)$, filtered again and then evaporated to dryness. The crude solid product was then recrystallised (hot hexanes) to give the colourless product 3b (1.65 g: 74\%) having a mp of $108-109{ }^{\circ} \mathrm{C}$ (lit. ${ }^{29} \mathrm{mp}$ : 105-106 $\left.{ }^{\circ} \mathrm{C}\right) .{ }^{1} \mathrm{H}$ NMR (400 MHz, RT, $\left.\mathrm{CDCl}_{3}\right): \delta_{\mathrm{H}}=10.10(\mathrm{br}$, $1 \mathrm{H}, \mathrm{OH}$ ), 7.84-7.82 (d, 2H, $J=9.2 \mathrm{~Hz}, \operatorname{Ar} H$ ), 6.89-6.87 (d, 2H, $J=8.8 \mathrm{~Hz}, \mathrm{ArH}), 5.53(\mathrm{~s}, 1 \mathrm{H}, \mathrm{CH}), 4.10\left(\mathrm{~s}, 2 \mathrm{H}, \mathrm{CH}_{2}\right), 3.81(\mathrm{~s}, 3 \mathrm{H}$, $\left.\mathrm{OCH}_{3}\right), 1.39\left(\mathrm{~s}, 6 \mathrm{H}, \mathrm{CH}_{3}\right)$; these data are consistent with that reported ${ }^{29}$ previously. ${ }^{13} \mathrm{C}\left\{{ }^{1} \mathrm{H}\right\}$ NMR (75 $\left.\mathrm{MHz}, \mathrm{RT}, \mathrm{CDCl}_{3}\right): \delta_{\mathrm{C}}=$ 27.1, 55.3, 58.4, 73.3, 78.8, 113.3, 128.6, 130.9, 132.6, 161.6, 169.4, 186.7 .

Synthesis of 3f. Stage 1: a sample of $(3 \mathrm{a} S, 8 \mathrm{a} R)-2$-methyl8,8a-dihydro-3a $H$-indeno[1,2-d]oxazole (1f; $0.42 \mathrm{~g}$ : $2.43 \mathrm{mmol}$; synthesised and characterised as previously reported ${ }^{31}$ ) was dissolved in a mixture of $\mathrm{MeCN}(20 \mathrm{~mL})$ and $\mathrm{NEt}_{3}(0.67 \mathrm{~mL}$ : $4.86 \mathrm{mmol}$ ). Benzoyl chloride (0.56 mL: $4.86 \mathrm{mmol}$ ) was then added by syringe and the mixture slowly heated to reflux temperature. A gradual colour change from colourless to yellow to orange was noted. After $4 \mathrm{~h}$, the reaction flask was cooled to RT. All volatile components were then removed by rotary evaporation using a bath temperature of between $50-60{ }^{\circ} \mathrm{C}$. The resulting brown-coloured solid was then extracted with EtOAc $(2 \times 30 \mathrm{~mL})$ and water $(50 \mathrm{~mL})$. The residual solids and aqueous layer was again extracted $\left(\mathrm{CHCl}_{3}: 30 \mathrm{~mL}\right)$ and the organics combined, washed with $5 \%$ aq. $\mathrm{NaHCO}_{3}$, and dried $\left(\mathrm{Na}_{2} \mathrm{SO}_{4}\right)$. This mixture was then filtered, and evaporated 
(rotovap) to give the crude, dark yellow solid of $(Z)-2-((3 \mathrm{a} R)-3-$ benzoyl-3,3a,8,8a-tetrahydro- $2 H$-indeno[1,2- $d$ ]oxazol-2-ylidene)1-phenylethanone (2f). Recrystallisation of this material (toluene-hexanes) gave the pale yellow product (mp: 206-206.5 ${ }^{\circ} \mathrm{C}$. Elemental analysis (\%); calc'd. (found) for $\mathrm{C}_{25} \mathrm{H}_{19} \mathrm{NO}_{3}$ : C 78.72 (78.29); H 5.02 (5.00); N 3.67 (3.69). ${ }^{1} \mathrm{H}$ NMR (400 MHz, RT, $\mathrm{CDCl}_{3}$ ): $\delta_{\mathrm{H}}=7.60-7.21(\mathrm{~m}, 14 \mathrm{H}, \mathrm{ArH}), 6.12$ (d, $1 \mathrm{H}, J=6.0 \mathrm{~Hz}, \mathrm{CHN}), 5.56(\mathrm{~m}, 1 \mathrm{H}, \mathrm{CHHCHO}), 5.37(\mathrm{~s}, 1 \mathrm{H}$, $\mathrm{C}=\mathrm{CH}$ ), 3.68-3.63 (dd, $1 \mathrm{H}, J=18.0 \mathrm{~Hz}, \mathrm{CH} H \mathrm{CH}), 3.45-3.39$ (dd, $1 \mathrm{H}, J=5.6,18.0 \mathrm{~Hz}, \mathrm{CHHCH}) ;{ }^{13} \mathrm{C}\left\{{ }^{1} \mathrm{H}\right\}$ NMR (75 MHz, RT, $\left.\mathrm{CDCl}_{3}\right): \delta_{\mathrm{C}}=37.8,65.8,83.6,85.4,125.5,126.8,127.2,128.0$, $128.1,128.2,129.0,129.9,131.3,131.9,134.3$, 138.4, 139.8, $140.0,158.9,168.5,186.8)$ in $50 \%$ yield $(0.54 \mathrm{~g})$. This material was then used directly in stage 2. Stage 2: A $0.38 \mathrm{~g}$ sample of $2 \mathrm{f}$ $(1.0 \mathrm{mmol})$, isolated as above, was treated with $50 \mathrm{~mL}$ of $1.5 \mathrm{M}$ $\mathrm{KOH}$ in $\mathrm{MeOH}$ and the resulting deep yellow coloured mixture stirred at RT for $6 \mathrm{~h}$. The (now dark orange coloured) solution was then filtered and the mixture extracted with $\mathrm{CHCl}_{3}$ $(30 \mathrm{~mL})$ and water $(3 \times 50 \mathrm{~mL})$. The organic fraction was isolated, dried $\left(\mathrm{Na}_{2} \mathrm{SO}_{4}\right)$, filtered and evaporated to give the crude brown coloured solid. This material was then recrystallised from a toluene-hexanes mixture; yield: $0.14 \mathrm{~g}$ (50\%). mp: 211.5-212 ${ }^{\circ} \mathrm{C}$. Elemental analysis (\%); calc'd. (found) for $\mathrm{C}_{18} \mathrm{H}_{15} \mathrm{NO}_{2}$ : C 77.96 (77.07); H 5.45 (5.57); N 5.05 (4.93). ${ }^{1} \mathrm{H}$ NMR (400 MHz, RT, $\mathrm{CDCl}_{3}$ ): $\delta_{\mathrm{H}}=10.63(\mathrm{~s}, 1 \mathrm{H}, \mathrm{NH}), 7.84-7.30$ $(\mathrm{m}, 9 \mathrm{H}, \operatorname{Ar} H), 5.57(\mathrm{~s}, 1 \mathrm{H}, \mathrm{C}=\mathrm{CH}), 5.55-5.51(\mathrm{~m}, 1 \mathrm{H}, J=1.6$, 5.6, $7.2 \mathrm{~Hz}, \mathrm{CHHCH}$ ), 5.50-5.48 (dd, $1 \mathrm{H}, J=7.2 \mathrm{~Hz}, \mathrm{CHN}$ ), 4.02-3.98 (dd, $1 \mathrm{H}, J=16 \mathrm{~Hz}$ ), 3.91-3.87 (dd, $1 \mathrm{H}, J=16 \mathrm{~Hz}$ ), 3.52-3.46 (dd, $1 \mathrm{H}, J=5.6,18.0 \mathrm{~Hz}, \mathrm{CH} H \mathrm{CH}$ ), 3.44-3.39 (dd, $1 \mathrm{H}, J=1.2,18.0 \mathrm{~Hz}, \mathrm{CHHCH}) ;{ }^{13} \mathrm{C}\left\{{ }^{1} \mathrm{H}\right\} \mathrm{NMR}$ (75 MHz, RT, $\left.\mathrm{CDCl}_{3}\right): \delta_{\mathrm{C}}=38.5,64.5,74.1,83.8,125.0,125.5,126.8,128.0$, 128.1, 128.6, 129.4, 130.5, 139.3, 139.7, 169.7, 187.0.

Synthesis of 5 . To a $50 \mathrm{~mL}$ round-bottomed flask was added 3a (0.50 g: $2.3 \mathrm{mmol})$ and $95 \%$ aq. EtOH $(10 \mathrm{~mL})$. The mixture was then stirred until all contents had dissolved. A sample of $\mathrm{Cu}\left(\mathrm{NO}_{3}\right)_{2} \cdot 2.5 \mathrm{H}_{2} \mathrm{O}(0.27 \mathrm{~g}: 1.2 \mathrm{mmol})$ was added to the solution; an immediate colour change from yellow to green was observed. After stirring for $6 \mathrm{~h}$, the solvent was reduced (vacuo) to a volume of about $2 \mathrm{~mL}$ and the flask then placed in a freezer $\left(-4^{\circ} \mathrm{C}\right)$ for $3 \mathrm{~h}$ to complete precipitation of the resulting powder. These green coloured solids were filtered off and then dried in vacuo. Recrystallisation was carried out using $\mathrm{CHCl}_{3}$ as solvent which was then layered with an equal volume of EtOH. This yielded material suitable for X-ray diffraction and analytical purposes after a period of $2-5 \mathrm{~d}$. Yield: $0.23 \mathrm{~g}$ (41\%). mp: $165{ }^{\circ} \mathrm{C}$ (decomp.). IR ( $\mathrm{KBr}, \nu, \mathrm{cm}^{-1}$ ): 3100-3000 (vw), 2962 (m), 1595 (vs), 1574 (s), 1536 (s), 1489 (s), 1308 (s), $1194(\mathrm{br}, \mathrm{m}), 1107(\mathrm{~m}), 756(\mathrm{~m}), 696(\mathrm{~m}) . \lambda_{\max }$ (acetone: 10 $10^{-4}$ $\mathrm{M})=443 \mathrm{~nm}\left(\varepsilon=1048 \mathrm{~L} \mathrm{~mol}^{-1} \mathrm{~cm}^{-1}\right)$. Elemental analysis (\%); calc'd. (found) for $\mathrm{C}_{36} \mathrm{H}_{28} \mathrm{~N}_{2} \mathrm{O}_{4} \mathrm{Cu}$ : C 62.95 (63.13); $\mathrm{H} 5.69$ (5.76); N 5.65 (5.66).

\section{Theoretical calculations}

Full geometry optimisations were carried out with the use of the B3LYP density functional level of theory ${ }^{32}$ using the 6-31G(d), 6-311G(d) and 6-311G(d,p) basis sets ${ }^{33}$ on all atoms (see ESI $\dagger$ ) for all materials studied except $\mathrm{Cu}$ complex 5; in this latter case the $6-31 \mathrm{G}(\mathrm{d})$ level only was employed. For the optimised geometries, harmonic vibrational frequencies were calculated at the B3LYP level. Single-point energies for the 6-311G(d) optimised geometries were calculated at the B3LYP/cc-pVTZ level of theory (except 5: 6-31G(d)). ${ }^{32,33}$ Solvation modelling was carried out using the SM8 or SMD solvation parameters at the $6-311 G(d)$ level of DFT. ${ }^{33}$ All calculations were carried out with using the Spartan 8.0, Spartan 10.0 and the Gaussian 3.0 suites of software. ${ }^{34,35}$

\section{Acknowledgements}

The authors thank the support of the Dean's Research Fund (Ryerson University) and NSERC (Canada) in the form of a Discovery Grant (RAG) and an USRA (TM), the ARC and our respective universities (Acadia, Ryerson, Saskatchewan, Toronto and Tasmania) for further support of this research. RAG is also indebted to the Royal Society of Chemistry for provision of a J. W. T. Jones Travelling Fellowship which provided key additional funding for this work.

\section{References}

1 For example: (a) M. Gómez, G. Muller and M. Rocamora, Coord. Chem. Rev., 1999, 193-195, 769-835; (b) A. Pfaltz, Acta Chem. Scand., 1996, 50, 189-194; (c) G. C. Hargaden and P. J. Guiry, Chem. Rev., 2009, 109, 2505-2550; (d) H. A. McManus and P. J. Guiry, Chem. Rev., 2004, 104, 4151-4202; (e) A. I. Meyers, J. Org. Chem., 2005, 70, 61376151; (f) G. Helmchen and A. Pfaltz, Acc. Chem. Res., 2000, 33, 336-345; $(g)$ V. A. Chebanov, K. A. Gura and S. M. Desenko, Top. Heterocycl. Chem., 2010, 23, 41-84.

2 B. M. Culbertson, Prog. Polym. Sci., 2002, 27, 579-626 and references therein.

3 For example: (a) R. H. Wiley and L. L. Bennett Jr., Chem. Rev., 1949, 44, 447-476; (b) J. A. Frump, Chem. Rev., 1971, 71, 483-505; (c) J. L. C. Wright, Proc. Nova Scotian Inst. Sci., 1984, 34, 133-162; (d) A. I. Meyers, J. Heterocycl. Chem., 1998, 35, 991-1002; (e) C. Lamberth, J. Prakt. Chem., 2000, 342, 518-522; $(f)$ V. I. Akhmedzhanova, D. Batsrunén and R. Sh. Shakirov, Khim. Prir. Soedin., 1993, 29, 873-876; (g) N. Okujo, M. Saito, S. Yamamoto, T. Yoshida, S. Miyoshi and S. Shinoda, BioMetals, 1994, 7, 109-116; (h) W. E. Houssen and M. Jaspars, ChemBioChem, 2010, 11, 1803-1815.

4 For example: W. W. Christie, Lipids, 1998, 33, 343-353.

5 For example: (a) R. A. Gossage, P. N. Yadav, T. D. MacInnis, J. W. Quail and A. Decken, Can. J. Chem., 2009, 87, 368379; (b) R. A. Gossage, H. A. Jenkins, N. D. Jones, R. C. Jones and B. F. Yates, Dalton Trans., 2008, 3115-3122; (c) F. Baerlocher, R. Bucur, A. Decken, C. R. Eisnor, R. A. Gossage, S. M. Jackson, L. Jolly, S. L. Wheaton and R. S. Wylie, Aust. J. Chem., 2010, 63, 47-55; 
(d) A. A. Deshpande, R. A. Gossage, S. M. Jackson, J. W. Quail, A. L. Sadowy and P. N. Yadav, Z. Naturforsch., B: Chem. Sci., 2009, 64, 1046-1052; (e) M. W. Chojnacka, A. J. Lough, R. S. Wylie and R. A. Gossage, J. Mol. Struct., 2011, 991, 158-161.

6 A. I. Meyers, D. L. Temple, R. L. Nolen and E. D. Mihelich, J. Org. Chem., 1974, 39, 2778-2783.

7 (a) Y. Tohda, T. Kawashima, M. Ariga, R. Akiyama, H. Shudoh and Y. Mori, Bull. Chem. Soc. Jpn., 1984, 57, 2329-2330; (b) Y. Tohda, M. Morikawa, T. Kawashima, M. Ariga and Y. Mori, Chem. Lett., 1986, 273-274; (c) Y. Tohda, T. Yanagidani, S. Hiramatsu, N. Nishiwaki, K. Tani, K. Imagawa and M. Ariga, Bull. Chem. Soc. Jpn., 1997, 70, 2781-2790. Also see: (d) F. Castan, F. Denonne and D. C. H. Bigg, Synthesis, 1993, 1081-1083; (e) S. Chatterjee, G. Ye, Y. Song, B. L. Barker and C. U. Pittman Jr., Synthesis, 2010, 3384-3394; (f) A. Zhou and C. U. Pittman Jr., Tetrahedron Lett., 2005, 46, 20452048; (g) Y. Song, H. I. De Silva, W. P. Henry, G. Ye, S. Chatterjee and C. U. Pittman Jr., Tetrahedron Lett., 2011, 52, 4507-4511.

8 (a) A. D. Garnovskii and I. S. Vasil'chenko, Usp. Khim., 2005, 74, 211-234, (Russ. Chem. Rev., 2005, 74, 193-215); (b) A. D. Garnovskii, A. P. Sadimenko, I. S. Vasilchenko, D. A. Garnovskii, E. V. Sennikova and V. I. Einkin, Adv. Heterocycl. Chem., 2009, 97, 291-392; (c) F. Dénès, A. PérezLuna and F. Chemla, Chem. Rev., 2010, 110, 2366-2447; (d) C. Spino, Org. Prep. Proced. Int., 2003, 35, 1-140.

9 (a) J. Elguero, C. Marzin, A. R. Katritzky and P. Linda, The Tautomerism of Heterocycles (Adv. Heterocyclic Chem. Supplement 1), Academic Press, New York, 1976, ch. 4, pp. 266-501; (b) V. I. Minkin, A. D. Garnovskii, J. Elguero, A. R. Katritzky and O. V. Denisko, Adv. Heterocycl. Chem., 2000, 76, 157-323.

10 For example: (a) Y. J. Park, N. S. Sickerman, J. W. Ziller and A. S. Borovik, Chem. Commun., 2010, 46, 2584-2586; (b) K. Pyta, P. Przybylski, A. Huczyński, A. Hoser, K. Woźniak, W. Schilf, B. Kamieński, E. Grech and B. Brzezinski, J. Mol. Struct., 2010, 970, 147-154; (c) A. N. Dixit, K. V. Reddy, A. R. A. S. Deshmukh, S. Rajappa, B. Ganguly and J. Chandrasekhar, Tetrahedron, 1995, 51, 1437-1448; (d) M. Juhász, L. Lázár and F. Fülöp, J. Heterocycl. Chem., 2007, 44, 1465-1473; (e) M. M. Venter and V. Zaharia, Stud. Univ. Babes-Bolyai, Chem., 2007, 52, 103-109; (f) A. Amar, H. Meghezzi, A. Boucekkine, R. Kaoua and B. Kolli, C. R. Chim., 2010, 13, 553-560; (g) V. Zaharia, A. Silvestru, P. Verite, M. Vlassa, S. Imre and C. Silvestru, Rev. Chim., 2008, 59, 1249-1254; (h) G. Ye, S. Chatterjee, M. Li, A. Zhou, Y. Song, B. Lloyd Barker, C. Chen, D. J. Beard, W. P. Henry and C. U. Pittman Jr., Tetrahedron, 2010, 66, 2919-2927.

11 G. Gilli and P. Gilli, J. Mol. Struct., 2000, 552, 1-15 and references therein.

$12 N . b$. The keto-isomer can be distinguished from both the ( $Z$ )-enol and enamine forms due to the presence of a $-\mathrm{CH}_{2}$ group appending the $\mathrm{C}$-atom emanating from oxazoline ring position-2. This functionality therefore provides, via integration of the ${ }^{1} \mathrm{H}$ NMR signals, a method to distinguish this isomer versus that of the other two $=\mathrm{CH}$ - containing forms.

13 L. J. Farrugia, J. Appl. Crystallogr., 1997, 30, 565.

14 F. H. Allen, O. Kennard, D. G. Watson, L. Brammer, A. G. Orpen and R. Taylor, J. Chem. Soc., Perkin Trans. 2, 1987, S1-S19.

15 N.b., These materials give solid-state IR data (Nujol®) which does not yield clear evidence for $\mathrm{N}=\mathrm{C}$ nor $\mathrm{N}-\mathrm{H}$ functionalities due to considerable signal overlap in both of these regions. ${ }^{7}$ We attempted to observe the near-IR overtone vibrations associated with the $\mathrm{N}-\mathrm{H}$ unit $\left(3 \mathrm{a}\right.$ : $\mathrm{CCl}_{4}$ solution) but did not observe the characteristic overtone absorption around $6500-6900 \mathrm{~cm}^{-1}$ typical of heterocyclic secondary amines (e.g., pyrrole). A weak absorption observed at $5944 \mathrm{~cm}^{-1}$ cannot be distinguished from an aromatic $\mathrm{C}-\mathrm{H}$ overtone vibration; see, for example: (a) Z. Shen and J. R. Schlup, J. Appl. Polym. Sci., 1998, 67, 267-276; (b) D. L. Snavely, F. R. Blackburn, Y. Ranasinghe, V. A. Walters and M. Gonzalez del Riego, J. Phys. Chem., 1992, 96, 3599-3605; (c) E. W. Crandall, J. Chem. Educ., 1987, 64, 466-467; (d) R. F. Goddu and D. A. Delker, Anal. Chem., 1960, 32, 140-141; (e) K. B. Whetsel, W. E. Roberson and M. W. Krell, Anal. Chem., 1958, 30, 1598-1604; (f) R. A. Russell and H. W. Thompson, Proc. R. Soc. London, Ser. A, 1956, 234, 318-326.

16 (a) H.-G. An, Acta Crystallogr., Sect. E: Struct. Rep. Online, 2007, 63, o3357; (b) J. Wang, J. Bai and Y. Pan, Acta Crystallogr., Sect. E: Struct. Rep. Online, 2008, 64, 0106.

17 (a) V. Bertolasi, V. Ferretti, P. Gilli, X. Yao and C.-J. Li, New J. Chem., 2008, 32, 694-704; (b) R. I. Zubatyuk, O. V. Shishkin, L. Gorb and J. Leszczynski, J. Phys. Chem. A, 2009, 113, 2943-2952; (c) T. Steiner, Chem. Commun., 1998, 411-412; (d) A. Mohajeri, J. Mol. Struct. (THEOCHEM), 2004, 678, 201-205; (e) P. Lenain, M. Mandado, R. A. Mosquera and P. Bultinck, J. Phys. Chem. A, 2008, 112, 7898-7904; (f) R. I. Zubatyuk, Y. M. Volovenko, O. V. Shishkin, L. Gorb and J. Leszczynski, J. Org. Chem., 2007, 72, 725-735; (g) S. Abdalla and M. Springborg, J. Phys. Chem. A, 2010, 114, 5823-5829; (h) V. Bertolasi, P. Gilli, V. Ferretti, G. Gilli and K. Vaughan, New J. Chem., 1999, 23, 1261-1267; (i) P. Sanz, O. Mó, M. Yáñez and J. Elguero, J. Phys. Chem. A, 2007, 111, 3585-3591; (j) W. M. F. Fabian, L. Antonov, D. Nedeltcheva, F. S. Kamounah and P. J. Taylor, J. Phys. Chem. A, 2004, 108, 7603-7612.

18 M. Małecka, Struct. Chem., 2010, 21, 175-184.

19 (a) A. R. E. Carey, R. A. More O'Ferrall and B. A. Murray, J. Chem. Soc., Perkin Trans. 2, 1993, 2297-2302; (b) R. A. More O'Ferrall and B. A. Murray, J. Chem. Soc., Perkin Trans. 2, 1994, 2461-2470; (c) A. R. E. Carey, S. Eustance, R. A. More O'Ferrall and B. A. Murray, J. Chem. Soc., Perkin Trans. 2, 1993, 2285-2296; (d) A. R. E. Carey, R. A. More O'Ferrall, M. G. Murphy and B. A. Murray, J. Chem. Soc.,Perkin Trans. 2, 1994, 2471-2479; (e) A. R. Katritzky, I. Ghiviriga, D. C. Oniciu, R. A. More 
O'Ferrall and S. M. Walsh, J. Chem. Soc., Perkin Trans. 2, 1997, 2605-2608; (f) V. I. Minkin, A. V. Tsukanov, A. D. Dubonosov and V. A. Bren, J. Mol. Struct., 2011, 998, 179-191; (g) L. Antonov, W. M. F. Fabian, D. Nedeltcheva and F. S. Kamounah, J. Chem. Soc., Perkin Trans. 2, 2000, 1173-1179; (h) M. Flores-Leonar, N. Esturau-Escofet, J. M. Méndez-Stivalet, A. Marín-Becerra and C. AmadorBedolla, J. Mol. Struct., 2011, 1006, 600-605; (i) R. Dobosz, B. Ośmiałowski and R. Gawinecki, Struct. Chem., 2010, 21, 1037-1041.

20 (a) R. P. Bell, J. Chem. Soc., 1931, 1371-1382; (b) J. J. Howland Jr., D. R. Miller and J. E. Willard, J. Am. Chem. Soc., 1941, 63, 2807-2811; (c) R. Battino and H. L. Clever, Chem. Rev., 1966, 66, 395-463.

21 (a) V. Gutmann, Electrochim. Acta, 1976, 21, 661-670; (b) Y. Marcus, J. Solution Chem., 1984, 13, 599-624; (c) F. J. Luque, J. M. López-Bes, J. Cemeli, M. Aroztegui and M. Orozco, Theor. Chem. Acc., 1997, 96, 105-113.

22 A. V. Marenich, R. M. Olsen, C. P. Kelly, C. J. Cramer and D. G. Truhlar, J. Chem. Theory Comput., 2007, 3, 2011-2033.

23 (a) R. F. Ribeiro, A. V. Marenich, C. J. Cramer and D. G. Truhlar, J. Comput. Aided Mol. Des., 2010, 24, 317333; (b) H. Fang and Y. Kim, J. Phys. Chem. B, 2011, 115, 15048-15058; (c) S. Ito, T. Hirano, A. Sugimoto, H. Kagechika, S. Takechi and T. Yamaguchi, Chem. Pharm. Bull., 2010, 58, 922-927.

24 (a) J. Vicente, in The Chemistry of Metal Enolates: Part 1, ed. J. Zabricky, Wiley, 2009, ch. 6, pp. 313-353; (b) H. Lang and R. Buschbeck, in The Chemistry of Metal Enolates: Part 2, ed. J. Zabricky, Wiley, 2009, ch. 17, pp. 929-1017.

25 For example: (a) W. N. Wallis and S. C. Cummings, Inorg. Chem., 1974, 13, 988-991; (b) F. Bao, R. Ma, R. Ma and Y. Jiao, J. Coord. Chem., 2007, 60, 557-560; (c) X.-Q. Lü, F. Bao, B.-S. Kang, Q. Wu, H.-Q. Liu and F.-M. Zhu, J. Organomet. Chem., 2006, 691, 821-828; (d) D. M. Granum, P. J. Riedel, J. A. Crawford, T. K. Mahle, C. M. Wyss, A. K. Begej, N. Arulsamy, B. S. Pierce and M. P. Mehn, Dalton Trans., 2011, 40, 5881-5890; (e) I.-M. Lee, in Focus on Organometallic Chemistry Research, ed. M. A. Cato, Nova Science Publishers, Hauppauge, 2005, ch. 5, pp. 133-145.

26 L. Yang, D. R. Powell and R. P. Houser, Dalton Trans., 2007, 955-964.

27 (a) P. Sténson, Acta Chem. Scand., 1969, 23, 1514-1524; (b) W.-K. Dong, X.-Y. Dong, Y.-X. Sun, J.-C. Wu and S.-J. Xing, Acta Crystallogr., Sect. E: Struct. Rep. Online, 2010, 66, m1626; (c) W.-J. Tai, C.-H. Li, C.-Y. Li and B.-T. Ko, Acta Crystallogr., Sect. E: Struct. Rep. Online, 2010, 66, m1315; (d) W.-K. Dong, Y. Wang, J.-C. Wu and S.-T. Zhang, Acta Crystallogr., Sect. E: Struct. Rep. Online, 2011, 67, m91; (e) E. Wehman, G. van Koten, J. T. B. H. Jastrzebski, M. A. Rotteveel and C. H. Stam, Organometallics, 1988, 7,
1477-1485; $(f)$ J. Thorhauge, M. Roberson, R. G. Hazell and K. A. Jørgensen, Chem.-Eur. J., 2002, 8, 1888-1898; (g) S. Cabaleiro, P. Pérez-Lourido, J. Castro, J. Romero and J. A. García-Vázquez-Sousa, Transition Met. Chem., 2001, 26, 709-716; (h) P. Segĺa, M. Jamnický, M. Koman and T. Glowiak, Polyhedron, 1998, 17, 2765-2772; (i) G. K. Patra, I. Goldberg, A. Sarkar, S. Chowdbury and D. Datta, Inorg. Chim. Acta, 2003, 344, 7-14; (j) Z.-L. Lü, Z.-L. Liu and D.-Q. Zhang, Acta Crystallogr., Sect. C: Cryst. Struct. Commun., 2005, 61, m147-m150; (k) M. Koman, P. Segĺa, M. Jamnický and T. Glowiak, Acta Crystallogr., Sect. C: Cryst. Struct. Commun., 2000, 56, 554-555; (l) P. Segĺa, M. Koman and T. Glowiak, J. Coord. Chem., 2000, 50, 105117; (m) Y.-Z. Zhu, Z.-P. Li, J.-A. Ma, F.-Y. Tang, L. Kang, Q.-L. Zhou and A. S. C. Chan, Tetrahedron: Asymmetry, 2002, 13, 161-165; (n) D. A. Evans, J. S. Johnson and E. J. Olhava, J. Am. Chem. Soc., 2000, 122, 1635-1649; (o) J. Jiang, C. Duan, J. Bai and Y. Pan, Anal. Sci., 2006, 22, x153-x154; ( $p$ ) Y.-W. Chang and J.-J. Yang, Acta Crystallogr., Sect. E: Struct. Rep. Online, 2007, 63, m2126; (q) Y.-M. Zhang, K. Xian, T.-B. Wei and K.-B. Yu, J. Chem. Res., 2003, 27(S), 798-799; (r) M. Corsini, E. Grigiotti, F. Laschi, P. Zanello, J. Burgess, J. Fawcett and S. R. Gilani, Coll. Czech. Chem. Commun., 2003, 68, 1449-1460; $(s)$ P. N. Yadav, T. M. Barclay and R. A. Gossage, J. Nepal Chem. Soc., 2011, 28, 54-58; (t) P. S. E. Bungu, M. Schutte and G. Steyl, Acta Crystallogr., Sect. E: Struct. Rep. Online, 2012, 68, m1373.

28 A. G. Orpen, L. Brammer, F. H. Allen, O. Kennard and D. G. Watson, J. Chem. Soc., Dalton Trans., 1989, S1-S83.

29 X. Chen, X.-L. Wang, H.-Z. Lian, J.-J. Chen, Y. Pan and Y.-Z. Shi, Chin. J. Chem., 1999, 17, 80-83.

30 The intermediate compound $\mathbf{2 b}$ has been further characterised in the solid-state by single crystal X-ray diffraction and these data confirm the surmised formulation as depicted in Scheme 1; see: A. Petrov, R. C. Jones, D. G. Vaughan, A. J. Lough and R. A. Gossage, Crystals, 2011, 1, 229-235.

31 (a) K. Watanabe, T. Hirasawa and K. Hiroi, Chem. Pharm. Bull., 1992, 50, 372-379; (b) A. I. Meyers, K. Kamata and I. Agata, J. Org. Chem., 1998, 63, 3113-3116.

32 (a) A. D. Becke, J. Chem. Phys., 1993, 98, 5648-5652; (b) C. Lee, W. Yang and R. G. Parr, Phys. Rev. B: Condens. Matter, 1988, 37, 295-300.

33 (a) R. Krishnan, J. S. Binkley, R. Seeger and J. A. Pople, J. Chem. Phys., 1980, 72, 650-654; (b) A. D. McLean and G. S. Chandler, J. Chem. Phys., 1980, 72, 5639-5648; (c) M. J. Frisch, J. A. Pople and J. S. Binkley, J. Chem. Phys., 1984, 80, 3265-3269.

34 Spartan 8.0 and Spartan 10.0, Wavefunction, Inc., Irvine, CA, 2008 and 2011.

35 GAUSSIAN 3.0 (Revision E.01), Gaussian Inc., CT, 2008. 